\title{
The Composition Of Corporate Boards Of Directors: Pre- And Post-Sarbanes-Oxley
}

Dan Marlin, University of South Florida St. Petersburg, USA

Scott W. Geiger, University of South Florida St. Petersburg, USA

\begin{abstract}
The purpose of this study is to examine corporate board characteristics pre- and post-SarbanesOxley. More specifically, using a sample 1141 US publicly traded firms, board characteristics were identified and then changes in these characteristics were examined across the years 2001, 2004, and 2007. Our analyses reveal significant changes in 8 of 10 board characteristics examined. Implications and areas for future research are discussed.
\end{abstract}

Keywords: Corporate Governance; Board of Directors; Board Characteristics

\section{INTRODUCTION}

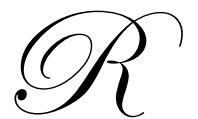

esearch on the board of directors and corporate governance has proliferated in the last decade. Indeed the wave of corporate scandals that came to light during the early 2000s brought the importance of sound corporate governance to the forefront of both public policy and academic research as many of the scandals can be directly attributed to failed corporate governance or more specifically to ineffective boards of directors. Corporate governance can be defined as the determination of the broad uses to which organizational resources are deployed and the resolution of conflicts among the many participants in organizations (Daily, Dalton, \& Cannella, 2003). More simply, corporate governance concerns the relationships between a company's shareholders, its board of directors, and managers. The primary role of the board of directors is to ensure that shareholders' interests are being best served by the decisions of those actually running the company, namely top managers. A second important role of the board is to provide resources that assist the organization in understanding and responding to its environment (Bear, Rahman, \& Post, 2010; Boyd, 1990).

From a public policy standpoint the major response to these scandals was the passage of the SarbanesOxley Act of 2002 that was signed in to law on July 30, 2002. The Sarbanes-Oxley Act amended U.S. securities as well as other laws and served to impact corporate governance in significant ways. The law applies to U.S. and nonU.S. public companies that have registered securities with the Securities Exchange Commission under the Securities and Exchange Act of 1934. As such, the act is far-reaching and impacts U.S. publicly traded firms. Since the passage of Sarbanes-Oxley, many company governance and board attributes have changed by legal mandate. However, as with any major external change to a given system changes occur that are both expected and unexpected. For instance, Sarbanes-Oxley required listing standards by exchanges that require a majority of board members to be independent from the company, thus limiting the influence of inside directors. However, the impact of this mandate is likely to have impacted other board characteristics. An example of this may be seen in changes in the diversity among boards in the areas of size, age, tenure, and gender. Further, it is likely that there have been longer term implications of the Sarbanes-Oxley Act on these same board characteristics.

The purpose of this study is to examine corporate board characteristics pre- and post-Sarbanes-Oxley. More specifically, using a sample 1141 US publicly traded firms, board characteristics were identified and then changes in these characteristics were examined across the years 2001, 2004, and 2007. In the next section, a brief overview of research on the importance of board characteristics is presented. Next, the methodology is described and the results of the analyses are presented. Finally, implications and future research areas are discussed. 


\section{LITERATURE REVIEW}

Two major organizational theories provide the theoretical rationale for the importance of board composition: agency theory and resource dependence theory. Indeed, according to Hillman and Dalziel (2003) boards of directors serve two important functions for organizations: monitoring managerial behavioral and providing resources. The monitoring function refers directly to the board's responsibility to monitor managerial behavior on the behalf of shareholders. One may presume that the composition of a board would aid in better monitoring. For example, inside directors may have less incentive to monitor management due to their dependence on the CEO and the organization (Hillman \& Dalziel, 2003). As such, boards dominated by independent outsiders (versus non independent insiders) are thought to do a better job of monitoring managers. As a further example, increased board size may increase the monitoring strength of the board of directors (Borokhovich, Brunarski, Harman, \& Kehr, 2005) due to greater oversight over the firm's management (Miller, 2009; Pearce \& Zahra, 1992). Larger boards may also enhance corporate governance by reducing CEO domination (Singh \& Harianto 1989).

The providing resources function refers directly to the ability of the board to bring resources such as advice, legitimacy, improved external communications, and support from important external elements to the firm (Hillman \& Dalziel, 2003). As seen with monitoring, it is expected that levels and types of resources brought to a firm by its board of directors are a function of the composition of the board. As an example, resource dependence theory suggests that a larger board yields benefits from the broader resource base presented by the larger size of the board. Thus, increasing board size can provide an increased pool of expertise and resources for the organization (Pfeffer, 1972) and may permit the inclusion of a variety of perspectives (Pearce \& Zahra, 1992). Further, larger board size may increase diversity among board members which in turn can increase board and firm performance (Bear et al., 2010).

Board diversity may also exist in age, tenure, gender, functional backgrounds, professional experiences, and education (Coffey \& Wang, 1998) and each in some way or another can affect the diversity of director resources and thus board composition and board performance. For example, prior research suggests that female directors tend to have different educational and professional backgrounds from those of male directors and may be more participative and democratic in decision-making processes (Bear et al., 2010). Further, certain amounts of board diversity with respect to age and tenure appear to be beneficial in boards (McIntyre, Murphy, \& Mitchell, 2007), as younger- and shorter-tenured directors are suggested on boards for a diversity of outlook (Bere, 1991; Siciliano, 1996) while older- and longer-tenured directors are likely to provide for some stability. Similarly, outside representation on boards creates more diversity and an enhanced level of cognitive conflict (Forbes \& Milliken, 1999) or differences in judgment, ideas, and viewpoints (Jehn, 1995) between board members. Finally, directors serving on multiple boards can provide the firm with a more diverse set of perspectives with regards to board dynamics and a greater level of knowledge of accepted practices on board diversity.

\section{METHODOLOGY}

\section{Sample and Data Collection}

The study sample included all firms in which complete data was available in The Corporate Library ${ }^{\circledR}$ Board Analyst database for the years 2001, 2004, and 2007. The years 2001 and 2004 were chosen since they are years before and after the complete implementation of the Sarbanes-Oxley Act of 2002. The year 2007 was chosen as a more recent time frame to compare to the earlier years and to allow for the examination and identification of longer terms changes in board characteristics as a result of the Sarbanes-Oxley Act of 2002. The starting sample included all firms in The Corporate Library® Board Analyst database in the year 2001 which primarily consisted of firms in the S\&P 500, S\&P MidCap 400, and S\&P SmallCap 600 Indices. The final sample consisted of 1141 firms for which complete data was available across each of the 3 years examined.

\section{Board Characteristic Measures}

We chose 10 measures for this study. These measures broadly covered general board characteristics like size and composition as well as other important areas like demographics and diversity. Variable means were 
calculated for each year of the study 2001, 2004, and 2007 and are reflective of the values of the measures as reported for each of the years examined.

Board size was calculated as the total number of directors on a given board (excluding Emeritus and Advisory member positions). Board tenure is the average number of years of service with the firm of board members. Board age was calculated as the average age of board members.

Tenure heterogeneity was calculated as the coefficient of variation for board tenure. The coefficient of variation is commonly used to capture demographic heterogeneity. Tenure heterogeneity measures the dispersion of the tenures of a firm's board members. Greater tenure heterogeneity would indicate greater dispersion in average tenures of board members and thus should indicate greater diversity. Likewise age heterogeneity was calculated as the coefficient of variation for board age and measures the dispersion in the ages of a firm's board members. Women directors was calculated as the sum of women directors on a given board divided by the total number of all directors on a given board.

Inside directors was calculated as the number of directors who are executives of the company divided by the total number of all directors on a given board. Directors over 70 years old was calculated as the sum of all directors over the age of 70 on a given board divided by the total number of all directors on a given board. Boards directors serve on is the average number of boards that directors of a company serve on. Directors failed attendance represents the number of directors that that have failed to meet the board's minimum attendance standards divided by the total number of all directors on a given board.

\section{Analysis}

Data from the 1141 firms sampled were analyzed using ANOVA and pairwise means comparisons. ANOVA was used to test whether significant differences in the board characteristics existed across the years 2001, 2004, and 2007. We then ran pairwise means comparisons on the board characteristics to establish between which of these years significant differences existed and the direction(s) of these differences.

Table 1 Variable Means and Tests for Longitudinal Differences in Board Characteristics

\begin{tabular}{lrrrrr}
\hline Variable & $\mathbf{5}$ & Year & & & F \\
\hline & $\mathbf{2 0 0 1}$ & $\mathbf{2 0 0 4}$ & $\mathbf{2 0 0 7}$ & Means Comparisons* \\
Board Size & 9.59 & 9.67 & 9.77 & 1.06 & - \\
Board Tenure & 9.14 & 9.09 & 8.88 & 1.33 & - \\
Board Age & 58.97 & 60.01 & 60.61 & $55.87 * * *$ & $2001<2004<2007$ \\
Tenure Heterogeneity & .712 & .753 & .785 & $25.46 * * *$ & $2001<2004<2007$ \\
Age Heterogeneity & .138 & .130 & .125 & $22.95 * * *$ & $2007<2004<2001$ \\
Women Directors (\%) & 8.72 & 10.43 & 12.03 & $38.84 * * *$ & $2001<2004<2007$ \\
Inside Directors (\%) & 30.03 & 17.49 & 15.72 & $488.92 * * *$ & $2007<2004<2001$ \\
Directors over 70 Years Old (\%) & 8.67 & 9.56 & 9.85 & $2.79+$ & $2001<2007$ \\
Boards Directors Serve On & 1.99 & 2.47 & 1.74 & $314.12 * * *$ & $2007<2001<2004$ \\
Directors Failed Attendance (\%) & 1.84 & 1.15 & 1.12 & $9.59 * * *$ & $2007,2004<2001$ \\
\hline
\end{tabular}

$\mathrm{n}-1141$

$+\mathrm{p}<.10 ; * \mathrm{p}<.05 ; * * * \mathrm{p}<.001$

\section{RESULTS}

Variables means and tests for differences in board characteristics across the three years examined for each of the 10 measures examined are presented in Table 1. Significant overall effects $(p<.10$ to $p<.001)$ were found for all but 2 (i.e., board size and board tenure) measures. In addition, pairwise means comparisons (also reported in Table 1) revealed significant differences $(\mathrm{p}<.05)$ across one or more years examined for each of the remaining 8 measures. More specifically, board age increased significantly from 2001 to 2004 and from 2004 to 2007; tenure heterogeneity increased significantly from 2001 to 2004 and from 2004 to 2007; age heterogeneity decreased 
significantly from 2001 to 2004 and from 2004 to 2007; women directors increased significantly from 2001 to 2004 and from 2004 to 2007; inside directors decreased significantly from 2001 to 2004 and from 2004 to 2007; directors over 70 years old increased significantly from 2001 to 2007 but not from 2001 to 2004 or from 2004 to 2007; boards directors serve increased significantly from 2001 to 2004 and then decreased significantly from 2004 to 2007 to below 2001 levels; directors failed attendance decreased significantly from 2001 to 2004 and from 2004 to 2007 .

\section{DISCUSSION AND CONCLUSIONS}

The purpose of this study was to examine corporate board characteristics pre- and post-Sarbanes-Oxley. More specifically, using a sample 1141 US publicly traded firms, board characteristics were identified and then changes in these characteristics were examined across the years 2001, 2004, and 2007. The results of our analyses reveal significant changes in 8 of 10 board characteristics examined. Implications of these results and areas for future research are discussed below.

The findings of this study highlight the shorter- and longer-term impact of the Sarbanes-Oxley Act on board characteristics. More specifically, from 2001 to 2004 significant changes were found in average board age, board tenure heterogeneity, board age heterogeneity, the percentage of women directors, the percentage of inside directors, the average number of boards served on, and the percentage of directors with failed attendance. Of particular interest are our findings of a significant increase in women directors and a significant decrease in inside directors suggesting both a greater diversity in gender and a greater diversity in resources provided by boards. Of further interest is the significant increase in the average number of boards served on. On the one hand this suggests a greater level and diversity of experiences of board members while on the other it suggests that at least some board members may be overextended. Finally, we also found a significant decrease in the percentage of board members who failed minimum attendance standards at board meetings suggesting improved board member behavior. Concerning the longer term impact of the Sarbanes-Oxley Act, changes in board characteristics continued to occur from 2004 to 2007 and with one exception (i.e., the average number of boards directors served on) mirrored the changes of the earlier time period.

The findings of this study also have implications for agency theory and resource dependence theory. Concerning agency theory, the significant increase in independent outside directors identified in our study should allow for better monitoring of managerial behavior and thus better corporate governance. Further, while we did not find significant changes in the average number directors on boards the trend does appear to be towards larger average board size. This combined with the trend toward greater levels of other types of diversity (i.e., tenure, gender, and professional experiences) which is expected to affect the diversity of resources brought to the firm by board members should also result in improved corporate governance.

There are also implications of this study for board design. In particular, this research is relevant for companies wishing to benchmark their board composition against that of other firms. Our findings may provide important information for firms considering making changes to their board. Further, and as discussed by McIntyre et al. (2007), those in charge of board design and those charged with finding new directors may find this type of research useful. In total, the results of this study combined with identified best practices of individual firms can be used to optimize board formation and board member selection.

Like most research efforts the current study has limitations that provide opportunities for future research efforts. First, this study was limited in its use of board characteristics. Thus future research may want to include additional measures. Additionally, the measures used in this study are observable board characteristics and are intended to be indicative of the idiosyncrasies of board members and their cognitive bases and values (Hambrick \& Mason, 1984). Future studies may benefit by examining board composition from a more qualitative perspective. A second limitation is that we did not examine performance in the current study. Future research would benefit from the examination of performance and of the linking of changes in board characteristics to changes in performance over time. Even with these limitations it is hoped that this study will serve as an important addition to the body of work examining boards of directors and corporate governance. 


\section{AUTHOR INFORMATION}

Dan Marlin is an Associate Professor of Management at the University of South Florida St. Petersburg. His research has been published in journals such as Nonprofit Management and Leadership, Journal of Managerial Issues, Strategic Management Journal, Health Services Research, and Health Care Management Review.

Scott W. Geiger is an Associate Professor of Management at the University of South Florida St. Petersburg. His research has been published in journals such as Organizational Behavior and Human Decision Processes, Organizational Research Methods, Journal of Business Ethics, and Journal of Business Research.

\section{REFERENCES}

1. Bear, S., Rahman, N., \& Post, C. (2010). The impact of board diversity and gender composition on corporate social responsibility and firm reputation. Journal of Business Ethics, 97, 207-221.

2. Bere, J.F. (1991). The director as servant and leader. Directors and Boards, 15(3), 7-8.

3. Borokhovich, K.A., Brunarski, K., Harman, Y., \& Kehr, J.B. (2005). Dividends, corporate monitors, and agency costs. The Financial Review, 40, 37-65.

4. Boyd, B. (1990). Corporate linkages and organizational environment: A test of the resource dependence model. Strategic Management Journal, 11, 419-430.

5. Coffey, B.S., \& Wang, J. (1998). Board diversity and managerial control as predictors of corporate social performance. Journal of Business Ethics, 17, 1595-1603.

6. Daily, M.D., Dalton, D.R., \& Cannella, A.A. (2003). Corporate governance: Decades of dialogue and data. Academy of Management Review, 28(3), 371-382.

7. Forbes, D.P., \& Milliken, F.J. (1999). Cognition and corporate governance: Understanding boards of directors as strategic decision-making groups. Academy of Management Review, 24, 489-505.

8. Hambrick, D.C., \& Mason, P.A. (1984). Upper echelons: The organization as a reflection of its top managers. Academy of Management Review, 9, 195-206.

9. Hillman, A.J., \& Dalziel, T. (2003). Boards of directors and firm performance: Integrating agency and resource dependence perspectives. Academy of Management Review, 28(3), 383-396.

10. Jehn, K. (1995). A multimethod examination of the benefits and detriments of intragroup conflict. Administrative Science Quarterly, 40, 256-282.

11. McIntyre, M.L., Murphy, S.A., \& Mitchell, P. (2007). The top team: Examining board composition and firm performance. Corporate Governance, 7(5), 547-561.

12. Miller, S.E. (2009). Governance mechanisms as moderators of agency costs in a pre-SOX environment. Journal of Business \& Economics Research, 7(10), 15-32.

13. Pearce, J.A., \& Zahra, S.A. (1992). Board composition from a strategic contingency perspective. Journal of Management Studies, 29(4), 411-438.

14. Pfeffer, J. (1972). Size and composition of corporate boards of directors: The organization and its environment. Administrative Science Quarterly, 17, 218-228.

15. Siciliano, J.I. (1996). The relationship of board member diversity to organizational performance. Journal of Business Ethics, 15: 1313-1320.

16. Singh, H., \& Harianto, F. (1989). Management-board relationships, takeover risk, and the adoption of golden parachutes. Academy of Management Journal, 32, 7-24. 
NOTES 